\title{
Poliovirus Receptor
}

National Cancer Institute

\section{Source}

National Cancer Institute. Poliovirus Receptor. NCI Thesaurus. Code C118556.

Poliovirus receptor (417 aa, $\sim 45 \mathrm{kDa}$ ) is encoded by the human PVR gene. This protein is involved in both natural killer cell activation and poliovirus binding. 